\title{
Preoperative embolization of a cerebellar haemangioblastoma using Onyx: case report and literature review
}

\author{
Przedoperacyina embolizacja naczyniaka płodowego móżdìku za pomoca \\ preparatu Onyx: opis przypadku i przeglqd piśmiennictwa
}

Ki Seong Eom, Dae Won Kim, See Sung Choi, Keum Ha Choi, Tae Young Kim

Wonkwang University College of Medicine, Iksan, South Korea

Neurologia i Neurochirurgia Polska 2011; 45, 3: 292-296

\begin{abstract}
Haemangioblastoma is a slow-growing, highly vascular tumour and typically occurs in the cerebellum but can also occur in the brainstem and spinal cord. Because of their hypervascularity and location, cerebellar haemangioblastomas can be difficult to remove. The purpose of preoperative embolization of haemangioblastomas is to decrease the intraoperative blood loss and to facilitate excision. However, the safety and efficacy of this procedure remain controversial. Here, we report the case of a man with cerebellar haemangioblastoma who underwent preoperative embolization with Onyx. The tumour was completely removed with minimal tumour bleeding. There was no complication related to embolization.
\end{abstract}

Key words: haemangioblastoma, embolization, Onyx.

\section{Introduction}

Haemangioblastoma is a slow-growing, highly vascular tumour that accounts for $2 \%$ of all intracranial tumours. It typically occurs in the cerebellum but can also occur in the brainstem and spinal cord [1]. Because of their hypervascularity and location, cerebellar haemangioblastomas can be difficult to remove. Uncon-

\section{Streszczenie}

Naczyniak płodowy to wolno rosnący i bogato unaczyniony guz, który zwykle występuje w móżdżku, ale może również umiejscawiać się w pniu mózgu lub rdzeniu kręgowym. Chirurgiczne usunięcie naczyniaka płodowego może być trudne ze względu na jego bogate unaczynienie i umiejscowienie. Celem przedoperacyjnej embolizacji tego guza jest zmniejszenie utraty krwi podczas operacji i ułatwienie jego wycięcia. Bezpieczeństwo i skuteczność tej procedury są jednak przedmiotem kontrowersji. W pracy przedstawiono opis przypadku chorego z naczyniakiem płodowym móżdżku, u którego wykonano przedoperacyjną embolizację za pomocą preparatu Onyx. Guz następnie usunięto, krwawienie podczas operacji było niewielkie. Nie obserwowano powikłań związanych z embolizacją.

Słowa kluczowe: naczyniak płodowy, embolizacja, Onyx.

trollable bleeding during surgical removal of cerebellar haemangioblastomas is associated with high rates of morbidity and mortality. Although preoperative embolization of haemangioblastomas has been considered helpful in some cases [2,3], the safety and efficacy of this procedure remain controversial. Recently, some authors advocated that particle embolization of cerebellar haemangioblastomas is quite hazardous and recom-

Correspondence address: Prof. Tae Young Kim, Wonkwang University College of Medicine, 344-2 Shinyong-dong, 570-711 Iksan, South Korea, e-mail: tykim@wonkwang.ac.kr

Received: 8.11.2010; accepted: 24.01.2011 

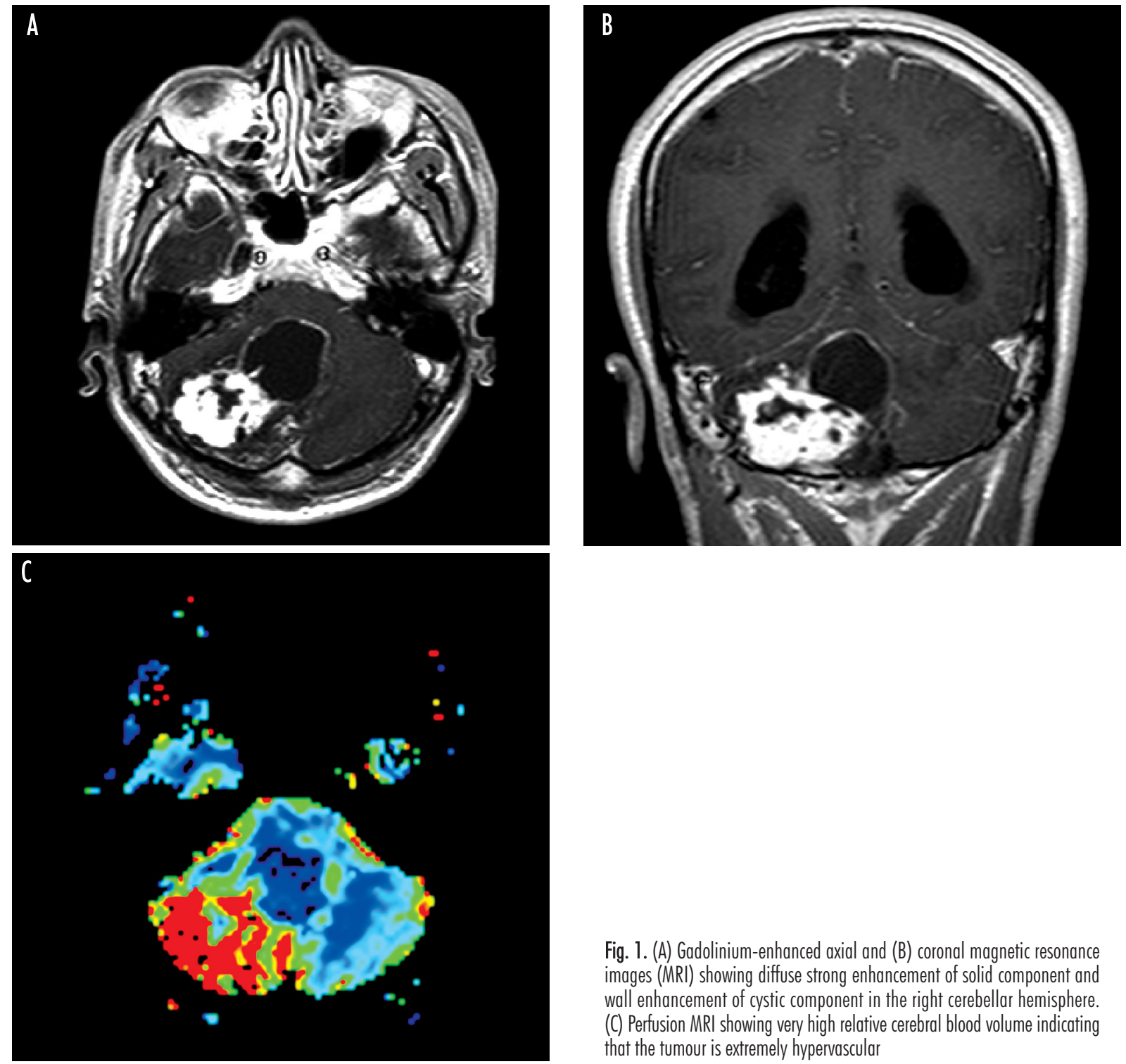

Fig. 1. (A) Gadolinium-enhanced axial and (B) coronal magnetic resonance images (MRI) showing diffuse strong enhancement of solid component and wall enhancement of cystic component in the right cerebellar hemisphere. (C) Perfusion MRI showing very high relative cerebral blood volume indicating that the tumour is extremely hypervascular

mended other embolization techniques such as transcranial intratumoural glue injection or transarterial proximal glue embolization $[4,5]$. Here, we report the case of a man with cerebellar haemangioblastoma who underwent preoperative embolization with Onyx, with a review of previous reports.

\section{Case report}

A 44-year-old man who had been experiencing dizziness and gait disturbances for one month was admitted to our hospital. His medical and surgical histories were unremarkable. Cranial magnetic resonance imaging

(MRI) revealed a solid mass (size, $55 \times 43 \times 46 \mathrm{~mm}$ ) with a large cyst in the right cerebellar hemisphere; the solid mass had a low signal intensity on the T1-weighted image and an inhomogeneous high signal intensity on the T2-weighted image. These images revealed diffuse strong enhancement of the solid component and wall enhancement of the cystic component after administration of a contrast agent, which suggested cerebellar haemangioblastoma. Multiple signal-void vascular structures within the tumour and obstructive hydrocephalus were noted. Perfusion MRI revealed very high relative cerebral blood volume, which indicated that the tumour was extremely hypervascular in nature (Fig. 1). 

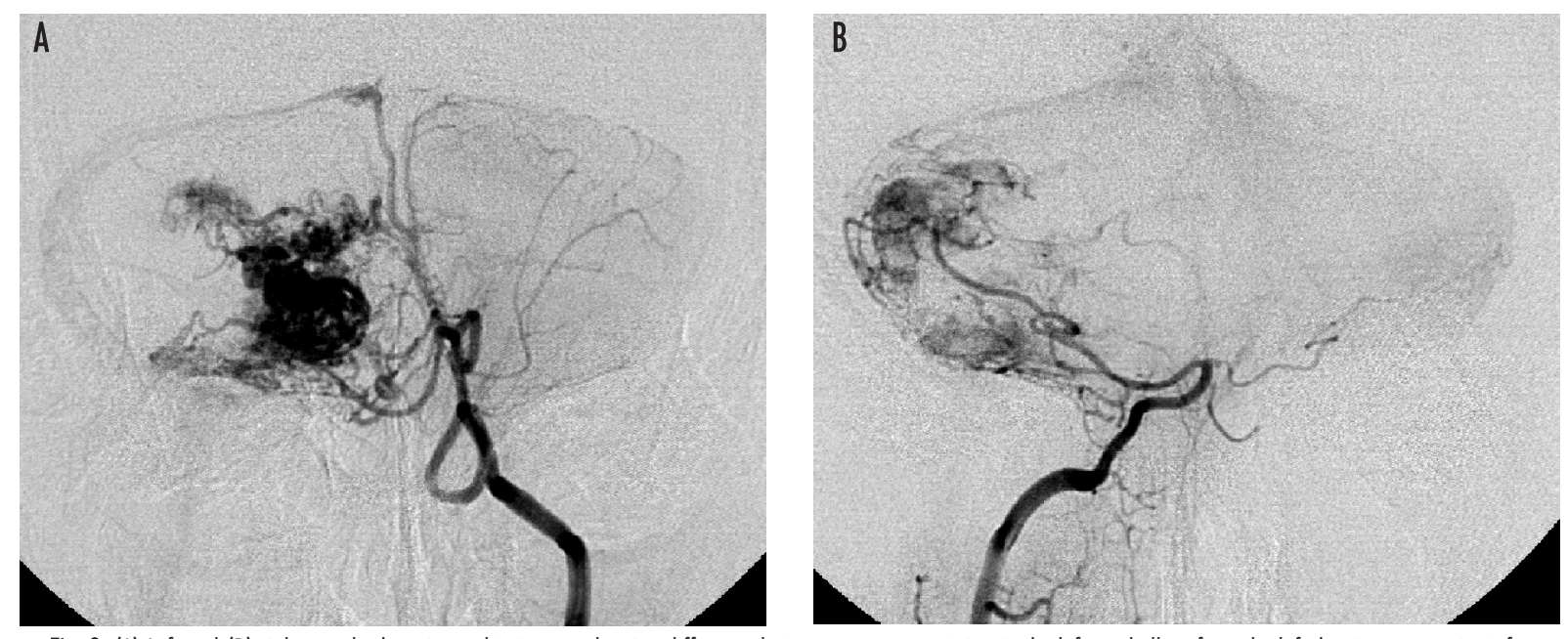

Fig. 2. (A) Left and (B) right vertebral angiographic images showing diffuse early intense tumour staining in the left cerebellum from the left dominant posterior inferior cerebellar artery (PICA) and the right anterior inferior cerebellar artery. Aneurysmal dilatation of the feeding artery of the left PICA within the tumour was noted

The results of whole-spine MRI and laboratory evaluation were unremarkable. Slit-lamp examination revealed both disc oedemas, which suggested papilloedema. Vertebral angiography revealed diffuse early intense tumour staining in the left cerebellum from the left dominant posterior inferior cerebellar artery (PICA) and right anterior inferior cerebellar artery (AICA) without significant early venous shunting or drainage. Aneurysmal dilatation of the feeding artery of the left PICA was noted within the tumour (Fig. 2).

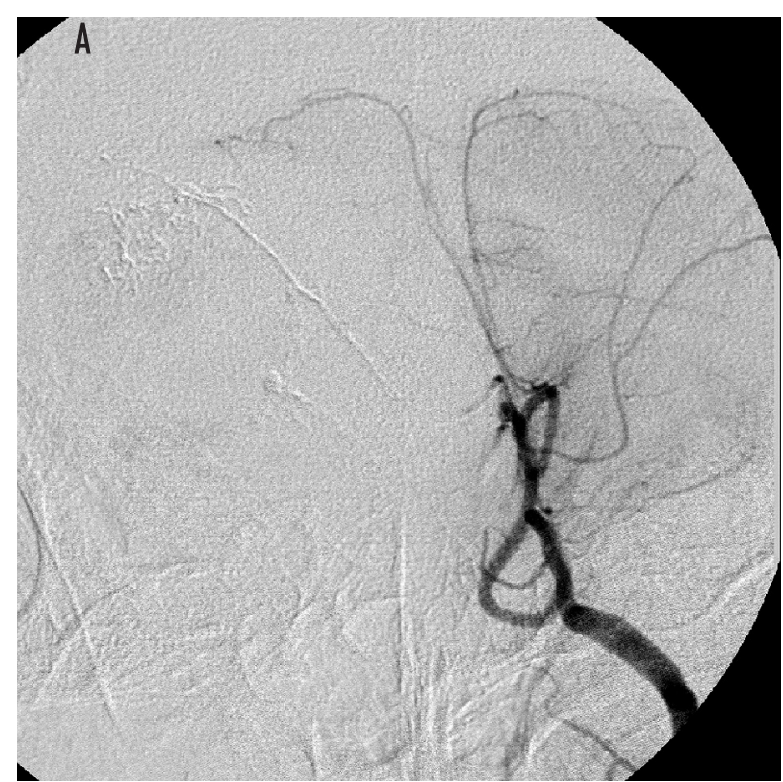

Fig. 3. (A) Left and (B) right post-embolization vertebral angiographic images showing the disappearance of most of the tumour staining from the left posterior inferior cerebellar artery and partial disappearance of tumour staining from the right anterior inferior cerebellar artery
Preoperative embolization using Onyx was performed via right transfemoral arterial access under local anaesthesia. Post-embolization angiography revealed that most of the tumour staining in the left PICA had disappeared and the tumour staining in the right AICA had disappeared partially (Fig. 3). A day after embolization, surgical removal of the mass via suboccipital craniotomy was performed. The tumour located beneath the dura mater was lobulated, rubbery, and well circumscribed (Fig. 4A). Surgery was performed under

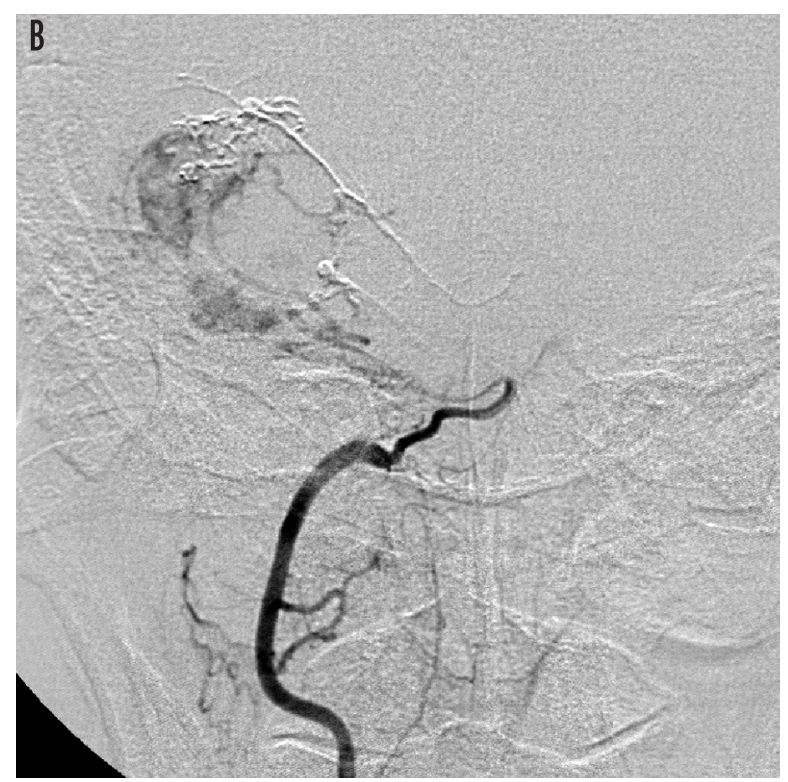



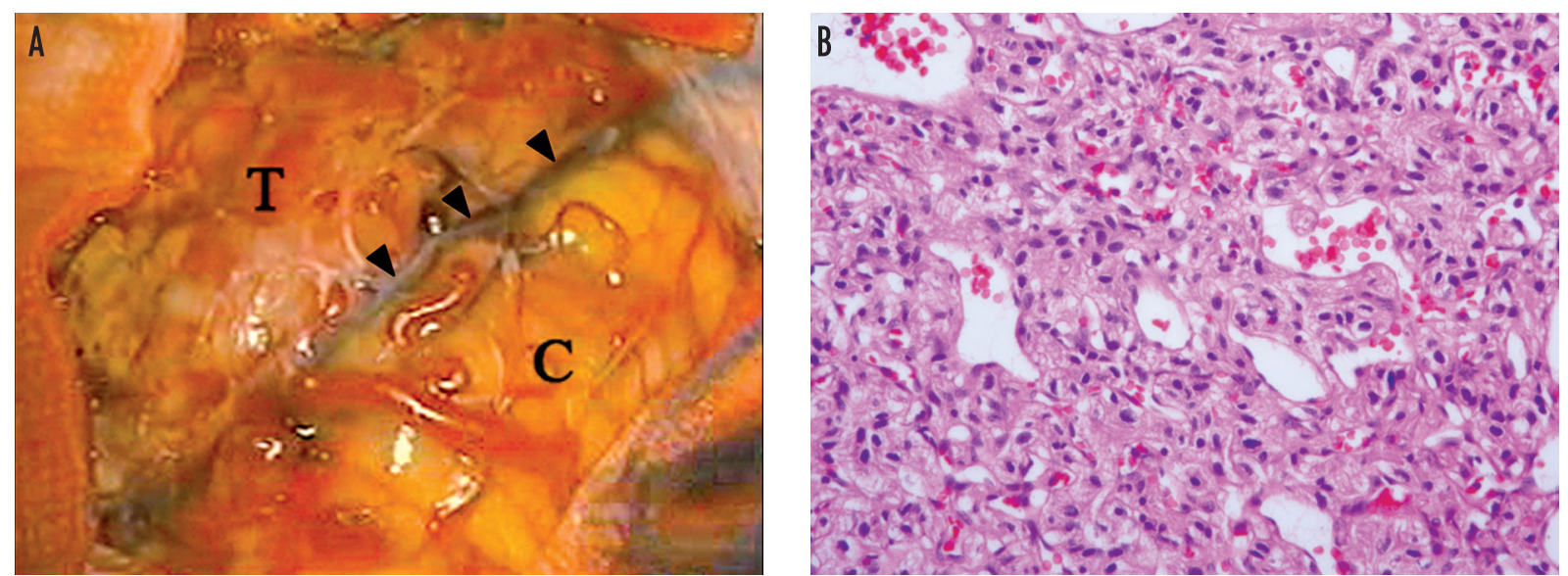

Fig. 4. (A) Intraoperative photograph obtained before resection of tumour showing lobulated and well-circumscribed mass. Onyx cast of distal posterior inferior cerebellar artery is noted (arrowheads). (B) Photomicrograph of the specimen showing haemangioblastoma composed of two main components: stromal cells that are characteristically large and vacuolated and abundant vascular cells (HE stain, $\times 400)(T-$ tumour; $C-$ cerebellum)

good conditions, and the tumour was completely removed with ease. There was no significant bleeding during the operation. Histological examination of the excised tumour revealed that the haemangioblastoma was composed of two main components: stromal cells that were characteristically large and vacuolated and abundant vascular cells (Fig. 4B). The stromal cells expressed S-100 protein and vimentin. The capillary endothelial cells were immunoreactive for endothelial cell markers such as cluster of differentiation 34 (CD34), and numerous thin-walled vessels were readily outlined by a reticulin stain. The patient showed no complications related to embolization and was discharged from the hospital on the $14^{\text {th }}$ day after the operation.

\section{Discussion}

Endovascular intervention has become a useful tool in the preoperative treatment of hypervascular tumours and in controlling intractable tumour bleeding [6]. The goal of tumour embolization is not just the sacrifice of the feeding vessel but also the obliteration of the tumour capillary bed to the greatest extent possible. There are three different types of embolic agents: mechanical devices, particles, and liquid agents. The choice of the optimal embolic agent depends on haemodynamic and angioarchitectural factors. Mechanical devices, including balloons and coils, can be used to decrease the blood flow in larger vessels to allow embolization with other materials [7].
Particles such as polyvinyl alcohol, Embospheres, and Gelfoam have been used successfully for preoperative embolization of tumours of the central nervous system (CNS) [7]. Although smaller particles more effectively penetrate the tumour capillary bed and achieve a greater degree of tumour embolization, they are more likely to migrate into normal vessels and embolize to the pulmonary capillary bed. Moreover, the particles are radiolucent, and contrast solution is required to indirectly visualize the extent of embolization [7]. Recently, some authors warned that particle-based embolization for cerebellar haemangioblastomas is associated with high mortality and morbidity rates. Cornelius et al. observed that the location of the haemangioblastoma is a reliable predictive factor of particle embolization safety [4]. Their review of the literature showed that the embolization-related complication rate in cases of spinal cord and brainstem haemangioblastomas was 5.6\%. However, particle embolization for cerebellar haemangioblastomas was associated with a higher rate of complications such as intratumoural haemorrhage or swelling. The complication rate in the cerebellum is $50 \%$ $[4,5]$. Cornelius et al. observed that their patients with cerebellar haemangioblastoma died because of haemorrhagic complications after embolization using Embospheres [4]. They hypothesized that the capillary diameters varied according to the tumour location, and posterior fossa haemangioblastomas bled because of the venous obstruction caused by particles and the subsequent congestion of tumour vessels, which led to rupture of the tumour. Montano et al. supported this hypo- 
thesis by performing histological examinations, wherein the embolizing particles were found in significantly higher levels in the venous spaces [5].

Liquid embolic agents include $n$-butyl cyanoacrylate (NBCA), dehydrated ethanol, and Onyx [5]. The advantages of NBCA include its radiopaque properties and its ability to achieve permanent vessel occlusion. In contrast to NBCA, Onyx is non-adherent to vessel walls, so a greater degree of reflux can be tolerated without the fear of catheter retention during embolization. The advantages of Onyx include its deep penetration of the tumour capillary bed, which often results in artery-to-artery embolization of tumour feeders [7]. Its other advantages include radiopacity, durability, availability in commercial formulations, relatively modest inflammatory activity, and the ability to allow angiography during embolization [7]. Onyx embolization also has some disadvantages. Injection over long distances in small-diameter or low-flow vessels is difficult $[7,8]$.

The role of Onyx in tumour embolization has not been well documented, and the available literature is largely limited to case reports and small case series. Gore et al. reported the safety and potential efficacy of Onyx in preoperative embolization of cranial and spinal tumours in a series of 10 patients [7]. They reported no complications related to embolization and concluded that this approach for tumours of the CNS is efficient and safe and allows deep penetration of the tumour with the embolic agent, thus reducing intraoperative blood loss and facilitating surgical resection. They also emphasized that excellent angiographic visualization is required to ensure that the agent does not cause anastomoses in the normal vasculature. To our knowledge, preoperative embolization of cerebellar haemangioblastomas by using Onyx has been reported in four cases in the literature [6-8]. All the tumours were successfully removed, and there was no complication related to embolization. These results show that Onyx is by far the better agent for cerebellar haemangioblastoma.

Since the medical literature on preoperative embolization of cerebellar haemangioblastoma by using Onyx is limited, the findings of this report will be useful. Preoperative embolization of cerebellar haemangioblastoma with Onyx can be performed safely and effectively and with potentially lower rates of intraoperative tumour bleeding. Because of its favourable characteristics, Onyx will probably be used more frequently for preoperative embolization of cerebellar haemangioblastoma. However, more studies must be conducted to prove that Onyx is better than other embolic agents.

\section{Acknowledgment}

This paper was supported by Wonkwang University in 2011 .

\section{Disclosure}

The authors report no conflict of interest.

\section{References}

1. Vates G.E., Auguste K.I., Berger M.S. Germ cell tumors. In: Berger M.S., Prados M.D. [eds.]. Textbook of neurooncology. Elsevier Saunders, Philadelphia 2005; pp. 294-300.

2. Standard S.C., Ahuja A., Livingston K., et al. Endovascular embolization and surgical excision for the treatment of cerebellar and brain stem hemangioblastomas. Surg Neurol 1994; 41: 405-410.

3. Tampieri D., Leblanc R., TerBrugge K. Preoperative embolization of brain and spinal hemangioblastomas. Neurosurgery 1993; 33: 502-505.

4. Cornelius J.F., Saint-Maurice J.P., Bresson D., et al. Hemorrhage after particle embolization of hemangioblastomas: comparison of outcomes in spinal and cerebellar lesions. J Neurosurg 2007; 106: 994-998.

5. Montano N., Doglietto F., Pedicelli A., et al. Embolization of hemangioblastomas. J Neurosurg 2008; 108: 1063-1064.

6. Elhammady M.S., Wolfe S.Q., Ashour R., et al. Safety and efficacy of vascular tumor embolization using Onyx: is angiographic devascularization sufficient? J Neurosurg 2010; 112: 1039-1045.

7. Gore P., Theodore N., Brasiliense L., et al. The utility of onyx for preoperative embolization of cranial and spinal tumors. Neurosurgery 2008; 62: 1204-1211.

8. Rehman T., Ali R., Yonas H. Cerebellar haemangioblastoma: temporising treatment in a high risk pregnancy. $B M J$ Case Reports, published 21 May 2009; available at: http://casereports.bmj.com/content/2009/bcr.01.2009.1413.abstract. 